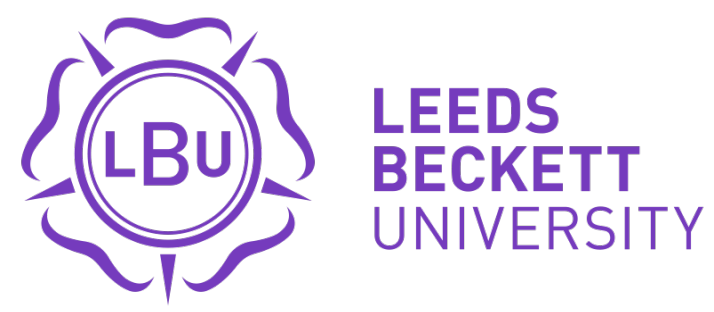

Citation:

Sharp, JG and Hemmings, B and Kay, R and Murphy, B and Elliott, S (2016) Academic boredom among students in higher education: a mixed-methods exploration of characteristics, contributors and consequences. Journal of Further and Higher Education. ISSN 1469-9486 DOI: https://doi.org/10.1080/0309877X.2016.1159292

Link to Leeds Beckett Repository record:

https://eprints.leedsbeckett.ac.uk/id/eprint/2271/

Document Version:

Article (Accepted Version)

The aim of the Leeds Beckett Repository is to provide open access to our research, as required by funder policies and permitted by publishers and copyright law.

The Leeds Beckett repository holds a wide range of publications, each of which has been checked for copyright and the relevant embargo period has been applied by the Research Services team.

We operate on a standard take-down policy. If you are the author or publisher of an output and you would like it removed from the repository, please contact us and we will investigate on a case-by-case basis.

Each thesis in the repository has been cleared where necessary by the author for third party copyright. If you would like a thesis to be removed from the repository or believe there is an issue with copyright, please contact us on openaccess@leedsbeckett.ac.uk and we will investigate on a case-by-case basis. 


\title{
Academic boredom among students in higher education: a mixed- methods exploration of characteristics, contributors and consequences
}

\author{
John G. Sharp ${ }^{1}$ \\ Brian Hemmings ${ }^{2}$ \\ Russell Kay ${ }^{2}$ \\ Barbara Murphy ${ }^{3}$ \\ Sam Elliott ${ }^{3}$ \\ ${ }^{1}$ School of Education and Childhood \\ Leeds Beckett University \\ Headingley Campus \\ Leeds LS6 3QS \\ UK \\ ${ }^{2}$ Research Institute for Professional Practice, Learning and Education \\ Charles Sturt University \\ Wagga Wagga \\ NSW 2678 \\ Australia \\ ${ }^{3}$ Centre for Educational Development and Research \\ Bishop Grosseteste University \\ Lincoln LN1 3DY \\ UK
}

Please direct all correspondence to the first author, Professor John G. Sharp

This article is protected until released for publication

(c) Sharp, Hemmings, Kay, Murphy and Elliott - March 2015 


\title{
Academic boredom among students in higher education: a mixed- methods exploration of characteristics, contributors and consequences
}

\begin{abstract}
Academic boredom contributes usually adversely towards student engagement, learning and overall performance across a diverse range of settings including universities. The formal study of academic boredom in higher education remains, however, a relatively underdeveloped field and one surprisingly neglected in the UK. Adopting contemporary perspectives rooted in Control-Value Theory, details of a mixed-methods exploration of academic boredom among 235 final year undergraduates attending a single university in England are presented. Quantitative data from the principal survey instrument employed included measurement using the BPS-UKHE, a revised boredom proneness scale developed for use across the sector. Qualitative data arose primarily from ten research interviews. Findings indicate that about half of all respondents reported experiencing the most common precursors of academic boredom at least occasionally (e.g. monotony, repetition, time slowing down, lack of desire for challenge, loss of concentration and motivation to learn, restlessness); traditional lectures with a perceived excess and inappropriate use of PowerPoint stimulating the actual onset of boredom more than other interactive forms of delivery. Coping strategies when bored included daydreaming, texting and turning to social media. Boredom also occurred during the completion of assignments used to assess modules. Quantitative and qualitative differences between those identified as more prone to boredom than others extended to selfstudy (fewer hours), attendance (good rather than excellent) and final degree outcome (lower marks and a lower proportion of first and upper second class degree awards). Findings are considered valuable empirically, as well as theoretically, leading to recommendations surrounding boredom mitigation which challenge cultural traditions and pedagogical norms.
\end{abstract}

Keywords: academic boredom, achievement-related emotion, Control-Value Theory, student engagement, mixed-methods, emotion-oriented teaching 


\section{Introduction and purpose}

Recently identified as a complex, achievement-related emotion, academic boredom contributes usually adversely towards student engagement, learning and overall performance across a diverse range of settings including universities (Schutz and DeCuir, 2002; Schutz and Pekrun, 2007; Linnenbrink-Garcia and Pekrun, 2011). Academic boredom's complexity arises because of its cognitive, affective, motivational and behavioural dimensions, as well as its highly situated and transient nature, which have traditionally rendered it difficult to define and locate theoretically, as well as to isolate and study (Pekrun et al., 2002; Vodanovich, 2003a; VogelWalcutt et al., 2012). Perhaps because of this, the formal study of academic boredom in higher education remains a relatively underdeveloped field and one surprisingly neglected in the UK (Mann and Robinson, 2009; Authors, 2015). Its formal study has also been impeded, perhaps, by the apparent 'universality' of boredom as a more widespread phenomenon and the misattribution of boredom to sometimes unrelated feelings or reactions to events (Fisher, 1993; Darden and Marks, 1999; Bardgill, 2000; Martin et al., 2006; Goldberg et al., 2011).

In this article, we provide a detailed overview of relevant research leading to the establishment of academic boredom as a field of enquiry in higher education before presenting findings from our own mixed-methods exploration of academic boredom among 235 final year undergraduates attending a single university in England. Quantitative data from the principal survey instrument employed included measurement using the BPS-UKHE, a revised boredom proneness scale developed for use across the UK Higher Education sector and reported earlier in this journal (Authors, 2015). Qualitative data providing reflections and comparative experiences of academic boredom came primarily from ten research interviews. The characteristics of boredom proneness and its relationship with different methods of course delivery are outlined. Those factors contributing towards the actual onset of academic boredom and its consequences are considered alongside its broader correlations and associations with mainly self-study hours, attendance and final degree outcome. Recommendations surrounding boredom mitigation are presented and discussed. 


\section{Review of literature}

An elusive and aversive state

According to Smith (1981), boredom attracted only sporadic interest as a general concept until the end of the 1970s, and from studies conducted by psychologists, psychotherapists and psychiatrists in mainly work-related settings. Throughout the 1980s, however, things changed. Already described as an elusive and aversive emotional state (the experience of boredom by an individual in any given moment), O'Hanlon (1981) noted that:

- boredom occurs as a reaction to task situations where the pattern of sensory stimulation is nearly constant or highly repetitive and monotonous;

- the degree of boredom reported by different individuals in the same working environment varies greatly;

- bored individuals may attempt to modify what they have to do or escape their working environment altogether;

- boredom can occur within minutes after starting something repetitive, particularly if frequently experienced in the past;

- boredom is highly situation-specific but also immediately reversible.

In an equally early attempt to provide a more comprehensive model with which to account for it, Perkins and Hill (1985) also considered boredom to arise from repetition and monotony, often resulting in high levels of frustration and unpleasantness along with low levels of interest and concentration. Soon afterwards, and perhaps for the first time in higher education, Moroldo (1986) reported a slight but significant and negative correlation between boredom and grade point average among students attending college in the United States.

A trait to be measured

In a shift of emphasis, and noting 'the disparity between the importance of boredom as an issue in ... education [and elsewhere] ... and the dearth of research with which 
to address it' (1986: 4), Farmer and Sundberg published their Boredom Proneness Scale (BPS), a 28-item questionnaire with which boredom as a trait (the recurring propensity or habitual disposition of an individual towards becoming bored) could be easily and reliably measured. Originally considered a unitary construct, the psychometric properties and underlying factor structure of the BPS soon became the subject of intense scrutiny, not only in the United States where it was first developed (Vodanovich and Kass, 1990a; Vodanovich et al., 1997; Vodanovich et al., 2005; Melton and Schulenberg, 2009) but in Canada (Ahmed, 1990), Australia (Gordon et al., 1997), France (Gana and Akremi, 1998) and Turkey (Dursun and Tezer, 2013). The inability to accurately replicate the factor structure of the BPS pointed not only to methodological issues in how replication was attempted but to culture-specific variation in boredom itself (Mercer-Lynn et al., 2011).

The impact of the BPS, particularly throughout the 1990s, and the notion that some people might be naturally more prone towards becoming bored than others, was considerable (Vodanovich, 2003a). Defined loosely, and after others, as 'a state of relatively low arousal and dissatisfaction ... attributed to an inadequately stimulating situation' (Mikulas and Vodanovich, 1993: 3), considerable effort, often involving students as participants, focused on the relationship between boredom and a variety of other human conditions and pathologies (Vodanovich and Kass 1990b; Rupp and Vodanovich, 1997; Watt and Vodanovich, 1999; Vodanovich, 2003b; Wallace et al., 2003). Following a more education-oriented study conducted by Harris (2000) in the United States, Mann and Robinson (2009) investigated boredom among students at a university in the north-west of England using a 'shortened' form of the BPS highlighting boredom proneness as an important factor contributing to the overall quality of the student experience. Inspired by their work and in response to reasonable claims that Farmer and Sundberg's BPS was constructed for more general purposes in a different cultural context, and now somewhat dated, the first phase of our own research resulted in a transformation of the BPS into the more contextualised BPS-UKHE used here (Authors, 2015).

Academic boredom within a 'trans-theoretical' framework 
According to Eastwood et al. (2012) and Fahlman et al. (2013), theories of boredom have traditionally fallen into four main camps: arousal-related (e.g. mismatches arising from the need for stimulation and its availability externally or environmentally), attention-related (e.g. failures of internal cognitive processes producing an inability to maintain focus), psychodynamic (e.g. the repression of desire to do something meaningful) and existential (e.g. from an emptiness or a lack of purpose in life). As indicated earlier, however, academic boredom is now considered a complex, achievement-related emotion and defined as an intense and often brief psycho-physiological change in response to a supposedly meaningful educational event (Pekrun et al., 2002). Evolving over time from attribution, expectancy and control theories (Weiner, 1985; Pekrun, 1992; Schönwetter et al., 1993; Perry, 2003; Hall et al., 2006), a more educationally fruitful and productive 'trans-theoretical' perspective acknowledging the 'hybridity' of academic boredom in 'real-life' educational settings has been proposed, particularly in relation to individuals becoming more effective learners by way of self-monitoring, selfregulation and metacognition (Zimmerman and Schunk 2001). Indeed, the now more evolved Control-Value Theory of Pekrun $(2000,2006)$ is of particular interest and relevance and it is within this framework our work is located.

In essence, Control-Value Theory predicts the outcome direction or 'valence' of educational tasks or activities (positive or negative) based upon the emotions aroused in relation to the importance attached to completing them. Summarised usefully by Ruthig et al. (2008), this occurs as students anticipate success or failure depending upon what they attribute to the successes or failures of the past and the extent to which they believe they can exert control or influence over those factors considered responsible. Students who believe control or influence is possible are thought more likely to exhibit higher levels of motivation and commitment towards their academic goals thereby improving their performance prospects. Negative emotions such as boredom (others include anxiety, anger, frustration, hopelessness, shame, disappointment, dissatisfaction and envy) are thought to impede the benefits of control.

Studies of mainly academic state boredom involving students from Germany, Canada, the United States, the Philippines and China using a range of 
methodologies and instruments to empirically test statements or hypotheses derived from Control-Value Theory are now available from within the field of applied or educational psychology (Pekrun et al., 2009, 2010; Ruthig et al., 2008; Goetz et al., 2010; Acee et al. 2010; Villavicencio and Bernardo, 2013; Tze et al. 2013a,b and $2014 a, b)$. Work of a broadly similar nature has also been undertaken in schools (Goetz et al., 2006; Frenzel et al., 2007; Nett et al., 2010, 2011; Daschmann et al., 2011), with a critical review of boredom in schooling provided by Belton and Priyadharshini (2007). These have consistently demonstrated academic boredom to operate at different levels in different ways (e.g. course-related, class-related, taskrelated, study-related and test-related). At their most advanced, Goetz et al. (2014) have published a typology of academic boredom from experience sampling in vivo and Pekrun et al. (2014) have demonstrated course-related academic boredom to have a negative effect on exams, and vice versa, suggesting reciprocal causation. We shall return to these contemporary perspectives in our discussion and conclusions.

\section{Methodology}

Research design, sampling and ethics

While previous studies have tended to focus almost exclusively on either academic trait or academic state boredom, our work here considers both, partly to replicate but also to develop and extend the work of Mann and Robinson (2009). Stepping back from psychology, which has dominated the field of research, this was undertaken as part of a mixed-methods exploration of academic boredom among three graduating cohorts of final year students following a combined honours Education Studies programme at a single university in England (Gorard, 2004; Johnson et al., 2007; Creswell and Plano-Clark, 2011). As a combined honours programme, education was studied in equal measure alongside one other academic discipline from a range of arts and humanities options. Sampling was both purposive and convenient with due consideration directed towards the overall aims and different phases of the project, its methodology (including access to personal and potentially sensitive information) and the elusive and situated nature of academic boredom itself. While the first phase of our work involved development of the BPS-UKHE (Authors, 2015), 
the second phase, reported here, uses quantitative data from the BPS-UKHE, as part of the principal survey instrument employed, in combination with qualitative data, obtained primarily from ten research interviews, to provide insight into the characteristics of boredom proneness and those factors which contribute to the actual onset of academic boredom and its consequences. Ethical approval was obtained in accordance with institutional policy as guided by the British Educational Research Association (BERA, 2011). Student participation remained entirely voluntary and by self-selection with informed consent.

\section{Quantitative data collection and analysis}

380 principal survey instruments, which included the BPS-UKHE, were distributed in situ during whole-year lectures as part of an educational research methods module. In addition, 380 'about you' questionnaires seeking demographic information were also distributed but later, along with others, over subsequent weeks during groupseminars. 309 survey instruments and 250 'about you' questionnaires were completed and subsequently returned (response rates of $81.3 \%$ and $65.8 \%$ respectively) resulting in a subsample of 235 usable items for which degree outcomes could also be matched. All quantitative data handling procedures were carried out using SPSS (version 22) adopting parametric as well as non-parametric statistical tests with Bonferroni corrections and effect sizes reported where appropriate (Field, 2009). In addition to the BPS-UKHE, the principal survey instrument also required respondents to provide information concerning how much of the time specific methods of course delivery interested or engaged them and why, why they found lectures and other forms of delivery particularly dull or boring, and what they did when bored (full details available upon request).

\section{Qualitative data collection and analysis}

On the basis of both high and low BPS-UKHE scores (see later), ten respondents were subsequently selected for interview in order to complement and inform quantitative findings by providing a richer source of data with which to attribute deeper meaning and better understand academic boredom and its influence (Tashakkori and Teddlie, 1998; Greene, 2007). Using pseudonyms, these included: 
- Hannah, Heather, Harriet, Holly, Harry and Howie (four females and two males scoring high - 88 to 99 );

- Lisa, Laura, Liam and Luke (two females and two males scoring low - 50 to 53).

The interviews were semi-structured and conducted by two of us in a relaxed manner in private to ensure a free and 'interactional exchange of dialogue' (Mason, 2000: 62) and flexibility in direction and response (Powney and Watts, 1987; Fontana and Frey, 2000; Schostack, 2006). During each interview (up to 1 hour in length), reflections surrounding the experience of academic boredom were brought into sharper focus. Initial questions raised included:

- What do you think are the main ingredients of an interesting/boring lecture?

- If you find yourself getting bored in a lecture what do you do?

- Do you find writing your assignments interesting/boring?

- What motivates you to keep going during an assignment?

- Are you able to devote as much time to your academic work as you would like?

Transcripts from audio-recordings were subsequently analysed manually by way of content analysis to identify relevant categories and emergent themes (Saldaña, 2013; Miles et al., 2014).

\section{Respondent profile}

Demographic information from the 'about you' questionnaire is presented as shown (Table 1). $59(25.1 \%)$ respondents were male and 176 (74.9\%) were female, figures typical of the degree programme as a whole. While 177 (75.3\%) started university soon after school or college, a range, including six over the age of $40(2.6 \%)$, provided an estimated sample mean of 24.3 years at the time of study. Entry qualifications were dominated by A-levels (204, 86.8\%) with Access (19, 8.1\%), BTECs $(9,3.8 \%)$ and International Baccalaureates (3, 1.3\%) providing alternative 
equivalents. Most started university as the first members of their immediate families ever to do so $(146,62.1 \%)$ and most described the occupational background of their immediate families as skilled, semi-skilled or unskilled manual $(133,56.6 \%)$. While $141(60.0 \%)$ respondents indicated working to earn while studying, the majority considered their attendance at university excellent $(153,65.1 \%)$.

[Insert Table 1 about here.]

\section{Presentation of findings}

\section{Characteristics}

From the literature review presented earlier, academic boredom, the boredom experienced by students while attending university (or any other higher education provider), may arise at any time, in any situation and take any number of different forms. The BPS-UKHE provides a relative measure of academic trait boredom, the recurring propensity or habitual disposition of students towards becoming bored at university as determined by the frequency with which certain boredom precursors or antecedents are reported (the 28 questionnaire items themselves - always scoring 5 to never scoring 1). Following reverse-item transformations, full-scale BPS-UKHE scores from all 235 respondents ranged from 41 to 106 (maximum possible range 28 to 140). These were normally distributed around a mean of 71.6 with a standard deviation of 12.17 (skewness $=0.156$, kurtosis=-0.218). Following the lead of Mann and Robinson (2009), three boredom proneness categories were established from a standard deviation split: low, intermediate and high. Operationalized in this way, all of the $45(19.1 \%)$ respondents scoring over 83 (mean score plus one standard deviation) were considered more prone to academic boredom than others (and therefore likely to get bored more easily and more often) than the $40(17.0 \%)$ respondents scoring less than 60 (mean score minus one standard deviation). Summary statistics which form the basis of all subsequent analyses are provided (Table 2). Further refinement and discussion is also possible with reference to the BPS-UKHE's five main subscales, Tedium, Time, Challenge, Concentration and Patience (Authors, 2015), and the response profiles and mean category scores of specific items within them (Table 3). 
[Insert Table 2 about here.]

\section{Tedium}

Boredom precursors: monotony, repetition, weariness, lack of excitement, meaninglessness, low arousal. Response profiles differed significantly across all ten statements from Item 28 to Item 18 (Wilcoxon's T=494.5, z=-11.55, p<.001; r=-.753). Reassuringly, perhaps, few respondents found everything about university tiresome or found themselves trapped in situations having to do meaningless things. More importantly, and with reference to Item 9, however, of the 134 (57.0\%) respondents who experienced repetition and monotony at least occasionally, 42 were particularly prone to boredom (93.3\% of the high category), 83 less so (55.3\% of the intermediate category) and 9 least of all (22.5\% of the low category). Similar patterns were observed throughout the subscale with significant differences across all mean category scores.

\section{Time}

Boredom precursors: perception of time passing slowly, inability to organise, manage or use time productively, general disinterest. Response profiles differed significantly across all eight statements from Items 16 to Item 23 (Wilcoxon's $T=1022.5, z=-$ 10.96, $p<.001 ; r=-.715)$. Again, few respondents found themselves with time on their hands or sitting around at a 'loose end' not knowing what to do. With reference to Item 3, however, of the $103(43.8 \%)$ respondents who considered time to pass by slowly for them at least occasionally, 33 were particularly prone to boredom $(73.3 \%$ of the high category), 68 less so (45.3\% of the intermediate category), and only 2 least of all (5.0\% of the low category). Similar patterns were observed throughout the subscale with only the mean category scores of Item 23 failing to reach statistical significance.

\section{Challenge}


Boredom precursors: perception of task demand in relation to ability, lack of desire for challenge or variety. Response profiles differed significantly across all three statements from Item 21 to Item 26 (Wilcoxon's $T=2132.0, z=-7.02, p<.001 ; r=-.458$ ). Few respondents felt they were working below their ability and not stretched enough. With reference to Item 26, however, of the $131(55.7 \%)$ respondents that felt they required a lot of change and variety at university to keep them really happy, 39 were particularly prone to boredom ( $86.7 \%$ of the high category), 85 less so $(56.7 \%$ of the intermediate category) and 7 least of all ( $17.5 \%$ of the low category). Only the mean category scores of Item 20 failed to reach significance.

\section{Concentration}

Boredom precursors: loss of concentration and motivation to learn, need for stimulation, inability to focus, attention deficit. Response profiles differed significantly across all three statements from Item 1 to Item 10 (Wilcoxon's $\mathrm{T}=1739.5, \mathrm{z}=-5.82, \mathrm{p}<.001 ; \mathrm{r}=-.380)$. With reference to Item 1 , and despite the low numbers involved, of the $61(26.0 \%)$ respondents who found it difficult to concentrate on their work and other activities at least occasionally, 28 were particularly prone to boredom $(62.2 \%$ of the high category), 30 less so $(20.0 \%$ of the intermediate category) and only 3 least of all (7.5\% of the low category). Significant differences were observed across all mean category scores

\section{Patience}

Boredom precursors: restlessness as a reaction to confining or restraining situations. The response profiles and mean scores of Items 15 and 17 differed significantly (Wilcoxon's $\mathrm{T}=2991.5, \quad \mathrm{z}=-4.26, \quad \mathrm{p}<.001 ; \quad \mathrm{r}=-.278)$. While only $93 \quad(39.6 \%)$ respondents considered themselves generally poor at waiting patiently at university at least occasionally (Item 15), 128 (54.5\%) reported getting restless while doing so (Item 17). Of those, 34 were particularly prone to boredom $(75.6 \%$ of the high category), 82 less so (54.7\% of the intermediate category) and 12 least of all (30.0\% of the low category).

[Insert Table 3 about here.] 
Academic boredom in profile

The differences in response profiles across all five subscales considered together were slight but, nevertheless, still significant, if only between some matched pairs (e.g. Concentration and Patience $t=-4.007, d f=234, p<.001 ; r=.253$ ). Split by boredom proneness category, however, important differences within the subscales were more apparent (Table 3). Presented more visually for ease of interpretation (Figure 1), not only did those respondents with a greater measured propensity towards becoming bored than others experience the precursors or antecedents of academic boredom more frequently, the nature of that experience also exhibited variation.

[Insert Figure 1 about here.]

\section{Contributors}

Interest and engagement

While the BPS-UKHE can be used as a first level diagnostic tool with which to identify and predict those students more prone to academic boredom than others, as well as to consider its precursor characteristics in detail, it reveals little about the circumstances surrounding the actual onset of academic boredom and how this is experienced in the moment. Turning initially to the different methods by which their course was delivered, respondents were asked to rate the extent to which each interested or engaged them (all of the time scoring 5 - none of the time scoring 1 ). Findings are presented as shown (Table 4). The differences in response profiles across all six methods common to their course and familiar to them were significant (Friedman's $\mathrm{x}^{2}=96.8, \mathrm{df}=5, \mathrm{p}<.001$; greatest contrast $\mathrm{r}=-.396$ ). Respondents expressed a clear preference for smaller and more interactive sessions over others (e.g. tutorials, practicals and seminars). This was also evident among both groups of interviewees (high and low BPS-UKHE scores). Reasons included having ready access to lecturers, opportunities for personalised and individualised support, social interaction, group work, the opportunity to share ideas and choice: 
'Sometimes it's just to clarify what I didn't understand in the lecture ... [W]hat helps me is when they break it all down. I like to go with my questions and make sure that those questions have been asked ... [T]he tutor doesn't know what I'm struggling with unless I bring that up. (Lisa)

[They're] not just spoon feeding you the information, [they're] provoking your thoughts, and letting you lead the conversation, rather than leading the conversation for you.' (Liam)

'We all kind of help each other in a way because everybody has different views ... There's always a debate or something being addressed.' (Hannah)

'You're there for a reason ... it's not like you're forced to go, you choose to go.' (Holly).

Interestingly, $166(70.6 \%)$ respondents found tutorials interesting or engaging most if not all of the time. Of the other $69(29.4 \%)$, only 18 were particularly prone to boredom $(40.0 \%$ of the high category), 45 less so $(30.0 \%$ of the intermediate category) and 6 least of all (15.0\% of the low category). By contrast, $109(46.4 \%)$ respondents found traditional, whole-year lectures interesting or engaging most if not all of the time, still a welcome finding running contrary to the popular 'demonization' of the lecture as a concept. Of the other 126 (53.6\%), however, 35 were particularly prone to boredom $(77.8 \%$ of the high category), 78 less so $(52.0 \%$ of the intermediate category) and 13 least of all (32.5\% of the low category). Not only did more respondents report being less interested or engaged, a greater proportion of those were more prone to boredom than others (significant differences in mean category scores also reflected lower levels of interactivity).

[Insert Table 4 about here.]

The lecture as a particular source of academic boredom and how it arises

Commenting generally on the main ingredients of an interesting or engaging lecture (as well as other forms of delivery), all respondents were clear in their views, with the perceived personal attributes and qualities of the lecturer top of their list (e.g. lively personality, humorous, stimulating, animated, enthusiastic, energetic, motivated and 
motivating, passionate). Variety and the relevance and coherency of content were also considered important (e.g. in the presentation of new knowledge and tasks, the effectiveness of explanations and questioning strategies, the use of guest speakers). These factors were evident among both groups of interviewees:

'I think the perfect lecture starts with having a tutor who's enjoying what they're doing.' (Lisa)

'I have to say in a way, a bit entertaining, 'cause I think that's a factor also.' (Harriet)

Only one interviewee focused on the very nature and perceived purpose of lectures as might be more commonly understood, as well as revealing something of his own motivation, stimulation and preferred approach to studying:

'A lecture should leave you asking questions of what you've been hearing, been listening to, and then want to go and find out something else about it. A lecture shouldn't be the lecturer going "there you go" ... Some of the best lectures l've had here have been really inspirational. (Luke)

When asked to comment on those factors which made lectures particularly dull or boring (as well as other forms of delivery), seven central themes emerged. Presented from the most commonly mentioned to the least, and paraphrasing from actual responses, these included:

- teaching and learning strategies (e.g. plain text PowerPoint, reading from PowerPoint slides or notes, unable to read the screen, skimming over or neglecting pre-session reading materials, lack of activities and tasks, poor explanations, too much to process in one sitting);

- $\quad$ personal attributes, style and qualities of the lecturer (e.g. individual perceived as boring, monotonous voice, endless talk, lack of interest or enthusiasm, lack of control);

- relevance (e.g. pointless or meaningless subject matter, repetition of material, no help with assignments or placements);

- coherency and pace (e.g. lack of structure, waffle, hard to keep up, too long, too slow, over-running and not keeping to time, breaks too long); 
- interaction (e.g. being talked at with no opportunity to contribute, debate or share, lack of questioning or challenge, no variety, discussions tedious).

- student behaviour (e.g. disruption or distraction by others, talking over the lecturer, lack of respect for the views of others, little contribution, late arrivals);

- environment (e.g. too hot, too stuffy, too noisy, too dark, difficulty hearing what is being said, sitting for too long, too intimidating).

At interview, a perceived excess and inappropriate use of PowerPoint also received considerable attention and attracted particular criticism (not PowerPoint per se). Qualitative differences between both groups of interviewees were obvious, including something of how boredom itself arose and how individuals responded. In Lisa's case, boredom happened infrequently and by distraction. The incentive to skip lectures was also presented:

I like PowerPoints but I don't like them just delivering a PowerPoint I could have just read ... I don't think lectures take me out of my comfort zone but sometimes I go out of my listening zone ... I think that's when I get bored, if they're just repeating something I could have done at home, I just think "Why am I here?" ... I get bored, like when I see other people are just on their phones or Facebook or you can see their laptop ... they're just not listening ... So it's not that I get bored a lot ... I just lose my concentration.' (Lisa)

The ability to re-engage when bored was particularly evident in Liam:

'My mind wanders sometimes but I manage to refocus and I'm one of those people who can, even if I'm not directly listening. I can still seem to catch information ... but I don't know why, I just seem to be able to do it.' (Liam)

For those more prone to boredom and for whom lecturers provided ample opportunity to become so, the issues surrounding PowerPoint and the environment in which it was used conveyed more serious implications (often with other achievement-related emotions coming into play):

'Sometimes when lecturers have used a lot of PowerPoints and not really interacted with everyone in the lecture theatre it becomes a bit monotonous and my brain switches off. I don't like it when people turn the lights off ... that makes me more sleepy ... The speed of the content that's been covered in the lecture, especially if it's new ... I get completely muddled ... and the rest 
of the lecture becomes a blur ... you're catching up ... not concentrating, completely lost, and panicking a bit ... I generally either doodle or go on social media ... I feel frustrated at myself because I feel like I should be concentrating ... It feels a bit pointless.' (Hannah)

\section{Consequences}

\section{Coping with boredom}

In addition to the comments above, and when asked what they actually did when bored, respondents admitted to 'daydreaming' and 'switching off' most commonly. Fortunately, few left class when the opportunity presented itself:

- daydream 107 (45.5\%);

- switch off $104(44.3 \%)$;

- text 87 (37.0\%);

- doodle or scribble over handouts 84 (35.7\%);

- talk to neighbour $64(27.2 \%)$;

- leave class at the break $13(5.5 \%)$;

- other $20(8.5 \%)$ - taking to Facebook, Twitter, the Internet, email or playing games on mobile phones; less commonly - falling asleep, making 'stupid noises' or comments, laughing out loud.

While each strategy was adopted by a greater proportion of those more prone to boredom than others, and in a greater number of combinations (mean 2.4 per person in the high category, 1.6 per person in the low category), the differences observed were only significant with texting $\left(\boldsymbol{K}^{2}=7.9, \mathrm{df}=2, \mathrm{p}<.05 ; \mathrm{V}=0.184\right)$. Among some of those more prone to boredom than others at interview, a strong sense of helplessness and inward-looking blame was attached to account for making little progress. This also provoked occasional reference to the financial cost of being at university:

I'm not taking anything in when I'm getting bored ... I doodle or clock watch ... or switch off ... it stops me falling asleep ... and then it's hard to get back into it again ... so I'm sort of walking out knowing the same as what I did when 
I walked in ... It sort of makes me feel like it's my fault, but if it doesn't interest me I get bored, there's nothing I can do.' (Heather)

If it's something completely off topic, irrelevant to me, I switch off ... [I]f I've got a personal matter l'll take care of that by email or whatever. If I've got a deadline [assignment] I'll try and focus on doing that. If there's literally nothing else l'll end up doing Facebook ... With regards the university, it makes me feel like it's a waste of money, a waste of time, especially 'cause of the distance I have to get to uni'.' (Howie)

For Howie, turning to other academic matters when bored in lectures indicated that at least some time was being used productively and that some coping strategies could be positive as well as negative.

\section{Course assessment and assignment boredom}

Beyond the sometimes far from optimal conditions surrounding engagement and learning presented, academic boredom also arose at interview in connection with the assessment of course modules, a process involving study on and off campus. On this programme, written assignments and presentations were the most common modes of assessment and the means by which final degree outcome was determined (the average mark from twelve assessed modules over two years). Examinations and tests were rare. At interview, the positive and negative influences of attempting to sustain the attention and motivation required to complete similarly presented assignments over time, with confidence emanating from attribution and expectation based upon previous successes or failures, were clearly different between groups. Other contributing factors included self-organisation, timemanagement, personal sacrifice, a sense of academic resignation and peer-pressure (again, with other achievement-related emotions often coming into play):

[W] hat l've found with my assignments is like the ones l've done well in, like two-ones [2:1s] or above, are the ones that I enjoyed writing ... [I]t makes me feel better so that in the next assignment I want to carry on feeling this good ... I don't fear doing badly, but I fear what other people are going to say ... that's a shame.' (Lisa) 
'Most of them I find quite interesting. I find it quite tedious towards the end ... I think because l've been at it so long and you just want to be finished.' (Laura)

II find [them] interesting at first but then it becomes more of a task and I find it boring. I think that sometimes it's fear of doing badly, but a lot of the time I'm working to the deadline and I'm constantly thinking "l've got to get this in" ... I think that's down to poor time management ... I think I want to do well, but I think it's the confidence sometimes, especially if l've had a previous assignment that's not had that much of a good mark.' (Hannah)

'Boring ... I put them off as long as I can 'cause ... it's just work and no one likes doing work ... I think there comes a time when you're just like, "oh, as long as it doesn't fail it's okay".' (Harry)

But the level of boredom experienced could also be moderated by the nature and type of assignment itself and the autonomy to choose what to study resulting in creativity and productivity:

'I think it depends on the topic. Like my dissertation. I loved writing it because it was something I picked ... I do quite like sitting and typing away, I just get carried away with my thoughts ... and then I feel I'm being productive. (Holly)

The cumulative effect of academic boredom on final degree outcome arising from course assessment should not, however, be underestimated (see later).

Academic boredom, final degree outcome and other correlates

Final degree marks from all 235 respondents at the conclusion of their course ranged from 43 to $80 \%$. These were normally distributed around a mean of $60.6 \%$ with a standard deviation of $6.65 \%$ (skewness $=-0.094$, kurtosis $=-0.029$ ). In terms of the demographic information collected from the 'about you' questionnaires, no immediate patterns or relationships were observed between BPS-UKHE scores or final degree outcome with age, entry qualifications, occupational background or university generation. With regard to gender, differences observed in boredom scores were marginal $(\mathrm{t}=1.919, \mathrm{df}=233, \mathrm{p}=.056)$, with male respondents scoring slightly higher than female (means 74.2 and 70.7 respectively). Correlations 
between boredom proneness, final degree mark, self-study hours, attendance and working to earn were, however, more revealing (Table 5). The directions of correlation were as predicted (both negative and positive e.g. BPS-UKHE score and final degree mark $r=-.315, p<.001$ ) with the exception of hours spent working to earn which failed to reach any level of significance.

[Insert Table 5 as close to here as possible.]

The same variables, split by boredom proneness category, are summarised and presented more visually as boxplots (Figure 2). Average degree outcome varied significantly across the three categories by up to 6 percentage points as indicated (ANOVA $F=10.3, d f=2,232, p<.001 ; \eta^{2}=.082$; greatest contrast $r=.418$ ). Similarly, self-study hours, which ranged from as few as 2 to one report of 50 hours (mean 13.7, SD 9.05), also varied significantly and by over 7 hours per week on average (ANOVA $\mathrm{F}=8.5, \mathrm{df}=2,232, \mathrm{p}<.001 ; \eta^{2}=.068$; greatest contrast $\mathrm{r}=.509$ ). Only 18 respondents considered particularly prone to boredom described their attendance as excellent $(40.0 \%$ of the high category) compared with 101 less so $(67.3 \%$ of the intermediate category) and 34 least of all (85.0\% of the low category). A simple regression model using BPS-UKHE score as the predictor variable for degree outcome revealed a weak but significant fit $(B=-0.315, t=-5.072, p<.001)$, with boredom proneness accounting for $9.9 \%$ of the overall variance observed $\left(R^{2}\right)$. Multiple regression using all five BPS-UKHE subscales revealed a more modest fit, accounting for $14.6 \%$ of the variance observed $\left(R^{2}\right)$, but with only Time and Concentration contributing significantly (Time $\quad B=-0.194, \quad t=-2.546, \quad p<.05$; Concentration $B=-0.258, \mathrm{t}=-3.247, \mathrm{p}<.01)$. Overall, and in accordance with institutional regulations governing degree classification, only 19 of those considered particularly prone to boredom obtained a first or upper second class honours degree (42.2\% of the high category) compared with 93 less so $(62.0 \%$ of the intermediate category) and 34 least of all (85.0\% of the low category), a significant association $\left(\kappa^{2}=16.5, \mathrm{df}=2, \mathrm{p}<.001 ; \mathrm{V}=0.227\right)$.

[Insert Figure 2 as close to here as possible.] 
Returning to assignment boredom and study on and off campus, the dedication and effort directed towards balancing priorities including working to earn and family commitments was commendable, but with qualitative differences in achievement motivation, goal-orientation, student identity and overall outlook sometimes evident between both groups of interviewees:

'Every piece of work is top quality, it has to be ... I had to have two extensions for my last two pieces of work, simply because l've got three kids, l've got a job, l've got a wife who works ... so l've got other pulls on my life ... I do most of my [course] work between half-past eight and two in the morning generally. It's the only time l've got so it's got to be productive ... you manage on hardly any sleep.' (Luke)

'If I'm not interested I'll be like "please get this module over and done with, l've had enough" ... I know there's going to be people out there who've got better grades than me but I might have a better experience than them, so it's important but it's not the sole importance in life ... I try to find time [for assignments] ... personal life makes it difficult ... struggling with two jobs, as well as bills and looking after a little 'un ... I tend to work better in the evenings so I might be up until three o' clock in the morning, get loads done, and just kip in the afternoon or something.' (Howie)

\section{Discussion}

\section{Overview}

Inspired by the work of Mann and Robinson (2009), findings from our own mixedmethods exploration of academic boredom among 235 final year undergraduates indicated that about half of all respondents reported experiencing the most common precursors of academic boredom at least occasionally (e.g. monotony, repetition, time slowing down, lack of desire for challenge, loss of concentration and motivation to learn, restlessness), some more frequently than that and others less so. In accordance with Control-Value Theory, and in terms of what contributed to the actual onset of academic boredom itself, respondents were generally less interested in or engaged by methods of course delivery within which the opportunity to contribute towards or exert any influence over events was minimal. Though by no means exclusively, this was particularly true of traditional, whole-year lectures. Lectures 
involving a perceived excess and inappropriate use of PowerPoint, along with other contributory factors, attracted particular criticism (though neither the lecture as a concept nor PowerPoint per se) and were deactivating in terms of arousal and sustaining attention (see Kinchin et al., 2008 and Fry et al., 2014). On those occasions when interest and engagement waned and boredom set in, respondents admitted to frequently daydreaming and simply switching off (most commonly) or texting, doodling, talking to neighbours, taking to social media and leaving class at the first opportunity (least commonly). What was not anticipated, though its function as more of a 'repository' than a 'blended learning tool' might be considered responsible, was the relatively poor positioning of online materials accessed via the institution's Virtual Learning Environment (Table 4).

In all areas explored, the characteristics, contributors and consequences of academic boredom described were most readily observed and acutely felt among those respondents identified as possessing a measurably greater recurring propensity or habitual disposition towards becoming bored than others as determined using the BPS-UKHE (the high boredom proneness category). Reflections at interview revealed important qualitative differences in the actual experience of academic boredom as a state, supporting the diagnostic value and predictive validity of the BPS-UKHE itself. Despite an ability to recognise when bored, those same individuals appeared less able to self-regulate and re-engage with the events taking place around them, seeking out alternative forms of stimulation instead, some of which were, on occasion, of an academic nature and productive. With reference to the typology provided by Goetz et al. (2014), examples of indifferent boredom (cheerful fatigue), calibrating boredom (wandering thoughts, at a loss for what to do), searching boredom (restlessness, seeking alternatives) and apathetic boredom (acquired helplessness) were most represented. Examples of reactant boredom (agitation with aggression in extremes) were notably and thankfully absent.

In accordance with Control-Value Theory, those respondents more prone to academic boredom than others appeared to do less well academically. Within the boundaries of the research undertaken, quantitative and qualitative differences extended to the number of hours devoted to self-study (fewer), attendance (good 
rather than excellent) and final degree outcome as a summative statement of academic performance (lower marks and a lower proportion of first and upper second class degree awards). Academic boredom certainly arose during the completion of assignments used to assess modules, the effects of which, with negative connotations and short term implications for some (e.g. lower assignment grades), may have combined incrementally with longer term consequences for others (academic boredom accounting for an appreciable amount of variance observed). While plausible and tempting to assume a causal relationship between boredom proneness and academic performance as described, directly or indirectly, reciprocally or mutually reinforcing (see Pekrun et al., 2014), findings at interview suggest that the complexity of boredom (e.g. its cognitive, affective, motivational and behavioural components) was more than matched by the complexity of life as a student, academic boredom's relationships with other intervening variables remaining somewhat clouded.

\section{Recommendations}

Findings demonstrate that academic boredom (course, class, task, study, test and, as discovered here, assignment related) can exert a sometimes strong influence over how students engage with and respond to the teaching-learning environment encountered at university. A central challenge to emerge, and featured elsewhere in the research literature, concerns itself not only with identifying when, where and how academic boredom arises, but, given the diversity of cultural traditions and pedagogical norms found within different departments and different disciplines across the sector, what can be done about this by way of intervention or prevention. It would not seem unreasonable to suggest, therefore, that boredom mitigation might begin by placing students at the heart of a transformational process which considers how courses are designed and delivered (e.g. Ramsden, 2003; Biggs and Tang, 2011) and how teaching for learning and assessment acknowledges academic boredom's debilitating effects. Such a position resonates with both Entwistle's (2009) heuristic approach to developing deeper levels of emotional attachment, satisfaction and understanding among students at university and Trowler's (2010) position on the UK student engagement agenda: 
'Student engagement is concerned with the interaction between the time, effort and other relevant resources invested by both students and their institutions intended to optimise the student experience and enhance the learning outcomes and development of students and the performance, and reputation of the institution.' (2)

With this in mind, and drawing on evidence from within the field including our own contribution, students should certainly be more involved in the ongoing development of their own courses at a variety of appropriate levels, while recognising that organised effort, attending to and improving their own learning and increasing their range of skills and competencies is an individual as well as shared responsibility (Ruthig et al., 2008; Pekrun et al., 2009, 2010). To help facilitate this, the academic requirements and emotional demands of transitioning into and throughout higher education should be more carefully articulated at induction during which the process of academic socialisation begins (e.g. independence as well as teamwork, relationships, motivation, attitude, taking initiative, learning how to learn, intentionality). The nature and purpose of the teaching-learning environment, together with the different forms of interaction and academic practice current at the time, should also be introduced. This also raises important and potentially uncomfortable questions about the induction and continuing professional development of lecturers, their relationships with students and with each other, and how course teams operate (Ashwin, 2015). In addition, students could be supported towards establishing new and distinctive ways of thinking and working by being provided with greater variety and freedom of choice over what to study and how, while making stronger connections between course content and the different contexts in which it is applied (Acee et al., 2010; Kass et al., 2011). Students for whom academic boredom proves troublesome or who find themselves identified as 'at risk' of falling behind or terminating studies as a result of academic boredom should be directed to pastoral tutors and learning development units, or counselling services in extremes, for advice and support, perhaps informed by 'attribution retraining' which has already proved useful elsewhere (e.g. Perry et al., 1993; Ruthig et al., 2004). More positive and constructive emotional reinforcement or conditioning might prove beneficial, improving resiliency and building confidence generally, while helping students to work through high-stress periods of formative and summative assessment which may cause anxiety and damage self-worth (Harris, 2000; 
Vodanovich, 2003b; Goetz et al., 2010). Finally, we join the call for innovative and better quality instruction in the form of more empathetic and emotion-oriented teaching (Tze et al., 2013a, 2014a).

\section{Limitations and directions for future research}

The work presented here makes no claim to fully capture the heterogeneity of higher education or the representativeness of other students taking different courses in different subject domains following different patterns and modes of study elsewhere, or, for that matter, the complexity of human behaviour reflected in the nature of academic boredom as described. Further research employing a variety of different designs and methodologies is certainly required at more 'local' and 'fine-grained' levels with participation from a broader and more diverse sample of the student population (e.g. longitudinal, cross-sectional, interventional and experimental). This should be undertaken as naturalistically as possible to ensure ecological validity if academic boredom is to be truly isolated, its relationships with other variables identified, corroborated and understood. In addition, data from the questionnaires employed relied upon self-reporting in the main, assuming a common reception and understanding of statements and terms, with the retrospective attribution of meaning and inferences drawn without the opportunity for independent verification beyond the interviews conducted. Our work also revealed little about whether or not academic boredom is 'imported' into or 'acquired' while at university, the stability of academic boredom (trait or state) and how this might change or evolve over the course of a degree, or about other forms of boredom and how these interact (e.g. leisure time boredom). As a result, we highlight the need for care when comparing studies, making generalisations and considering recommendations.

\section{Conclusions}

With academic boredom conceptualised as a complex and largely negative, achievement-related emotion, the findings presented here make an important empirical contribution to a relatively underdeveloped but growing and internationally recognised field of higher education research. Though surprisingly neglected in the UK, the adoption of a mixed methods approach drawing together quantitative data 
from questionnaires and qualitative data from interviews proved particularly effective in probing this otherwise transient, elusive and highly situated phenomenon. While more exploratory and inductive than explanatory and deductive, Control-Value Theory provided a robust and productive framework within which to locate our work as well as to provide the stimulus for future endeavours. With potentially far reaching implications and consequences, reinforcing the need to more fully understand the nature of the student experience and the potential impact of cultural traditions and pedagogical norms, our work helps establish academic boredom as an integral part of a learning dynamic and evolving causal network deserving of more serious consideration. While placing students at the heart of a transformational process in making recommendations surrounding boredom mitigation, we are, nevertheless, reminded by Hutchings and Shulman $(1999: 13,14)$ that:

'[A]ll faculty have an obligation to teach well, to engage students and to foster important forms of student learning ... When it entails ... certain practices of classroom assessment and evidence gathering, when it is informed not only by the latest ideas in the field but by current ideas about teaching the field, when it invites peer collaboration and review, then that teaching might rightly be called scholarly, or reflective, or informed ... A scholarship of teaching ... requires ... faculty [to] frame and systematically investigate questions related to student learning - the conditions under which it occurs, what it looks like, how to deepen it, and so forth - and do so with an eye not only to improving their own classroom but to advance practice beyond it ... [F]aculty in most fields are not, after all, in the habit of - nor do most have the training for framing [such] questions ... [or] ... the systematic enquiry that will open up those questions.'

If the ultimate vision over time is, as it for us and many others across the sector, to work collaboratively and in partnership with students to improve the quality of their higher education experience, as well as our own, while drawing back from an increasingly consumerist and utilitarian model of students as passive recipients motivated only by extrinsic reward, then the study of academic boredom and other achievement-related emotions may yet provide the impetus for driving professional dialogue and change.

\section{References}


Authors (2015) Towards a model for the assessment of student boredom and boredom proneness in the UK higher education context. Journal of Further and Higher Education.

Acee, T.W., Kim, H., Kim, H.J., Chu, H.R., Kim, M., Cho, Y. and Wicker, F.W. (2010) Academic boredom in under- and over-challenging situations. Contemporary Educational Psychology, 35(1), 17-27.

Ahmed, S.M. (1990) Psychometric properties of the boredom proneness scale. Perceptual and Motor Skills, 71, 963-966.

Ashwin, P. (ed.) (2015) Reflective teaching in Higher Education. London: Bloomsbury.

Bardgill, R.W. (2000) The study of life boredom. Journal of Phenomenological Psychology, 31(2), 188-219.

Belton, T. and Priyadharshini, E. (2007) Boredom and schooling: a cross-disciplinary exploration. Cambridge Journal of Education, 37(4), 579-595.

Biggs, J. and Tang, C. (2011) Teaching for quality learning at university. Maidenhead: Society for Research into Higher Education and Open University Press.

British Educational Research Association (2011) Ethical guidelines for educational research. London: BERA. [Available at: www.bera.ac.uk/researchersresources/publications/ethical-guidelines-for-educational-research-2011.

Creswell, J.W. and Plano-Clark, V.L.P. (2011) Designing and conducting mixed methods research. Thousand Oaks, CA: Sage.

Darden, D.K. and Marks, A.H. (1999) Boredom: a socially disvalued emotion. Sociological Spectrum, 19, 13-37.

Daschmann, E.C., Goetz, T. and Stupnisky, R.H. (2011) Testing the predictors of boredom at school: development and validation of the precursors to boredom scales. British Journal of Educational Psychology, 81(3), 421-440.

Dursun, P. and Tezer, E. (2013) Turkish adaptation of the boredom proneness scale short-form. Procedia: Social and Behavioural Sciences, 84, 1550-1554.

Eastwood, J.D., Frischen, A., Fenske, M. and Smilek, D. (2012) The unengaged mind: defining boredom in terms of attention. Perspectives on Psychological Science, 7(5), 482-495. 
Entwistle, N. (2009) Teaching for understanding at university. London: Palgrave Macmillan.

Fahlman, S.A., Mercer-Lynn, K.B., Flora, D.B. and Eastwood, J.D. (2013) Development and validation of the multidimensional state boredom scale. Assessment, 20(1), 68-85.

Farmer, R. and Sundberg, N.D. (1986) Boredom proneness: The development and correlates of a new scale. Journal of Personality Assessment, 50(1), 4-17.

Field, A. (2009) Discovering statistics using SPSS. London: Sage.

Fisher, C.D. (1993) Boredom at work: a neglected concept. Human Relations, 46(3), 395-418.

Fontana, A. and Frey, J.H. (2000) The interview: from structured questions to negotiated text. In: N.K. Denzin and Y.S. Lincoln (eds.) Handbook of Qualitative research. Thousand Oaks, CA: Sage. 645-672.

Frenzel, A.C., Pekrun, R. and Goetz, T. (2007) Perceived learning environment and students' emotional experience: a multilevel analysis of mathematics classrooms. Learning and Instruction, 17(5), 478-493.

Fry, H., Ketteridge, S. and Marshall, S. (eds.)(2014) A handbook for teaching and learning in higher education: enhancing academic practice. London: Routledge.

Gana, K. and Akremi, M. (1998) The scale of tendency towards boredom (EDE): French adaptation and validation of the Boredom Proneness Scale (BP). L'Anée Psychologique, 98(3), 429-450.

Goetz, T., Pekrun, R., Hall, N.C. and Haag, L. (2006) Academic emotions from a social-cognitive perspective: antecedents and domain specificity of students' affect in the context of Latin instruction. British Journal of Educational Psychology, 76(2), 289-308.

Goetz, T., Frenzel, A.C., Hall, N.C., Nett, U.E., Pekrun, R. and Anatstasiya, A.L. (2014) Types of boredom: an experience sampling approach. Motivation and Emotion, 38(3), 401-419.

Goetz, T., Frenzel, A.C., Stoeger, H. and Hall, N.C. (2010) Antecedents of everyday positive emotions: an experience sampling analysis. Motivation and Emotion, 34(1), 49-62. 
Goldberg, Y.K., Eastwood, J.D., Laguardia, J. and Danckert, J. (2011) Boredom: an emotional experience distinct from apathy, anhedonia, or depression. Journal of Social and Clinical Psychology, 30(6), 647-666.

Gorard, S. (2004) Sceptical or clerical? Theory as a barrier to the combination of research methods. Journal of Educational Enquiry, 5(1), 1-21.

Gordon, A., Wilkinson, R., McGowan, A. and Jovanskoska, S. (1997) The psychometric properties of the boredom proneness scale: an examination of its validity. Psychological Studies, 42(2\&3), 85-97.

Greene, J.C. (2007) Mixed methods in social inquiry. San Francisco, CA: JosseyBass.

Hall, N.C., Perry, R.P., Ruthig, J.C., Hladkyj, S. and Chipperfield, J.G. (2006) Primary and secondary control in achievement settings: a longitudinal field study of academic motivation, emotions and performance. Journal of Applied Social Psychology, 36(6), 1430-1470.

Harris, M.B. (2000) Correlates and characteristics of boredom proneness and boredom. Journal of Applied Social Psychology, 30(3), 576-598.

Hutchings, P. and Shulman, L. (1999) The scholarship of teaching: new elaborations, new developments. Change: The Magazine of Higher Learning, 31(5), 10-15.

Johnson, R.B., Onwuegbuzie, A.J. and Turner, L.A. (2007) Toward a definition of mixed methods research. Journal of Mixed Methods Research, 1(2), 112-133.

Kass, S.J., Vodanovich, S.J. and Khosravi, J. (2011) Applying the job characteristics model to the college education experience. Journal of the Scholarship of Teaching and Learning, 11(4), 56-68.

Kinchin, I.M., Chadha, D. and Kokotailo, P. (2008) Using PowerPoint as a lens to focus on linearity in teaching. Journal of Further and Higher Education, 32(4), 333-346.

Linnenbrink-Garcia, E.A. and Pekrun, R. (2011) Students' emotions and academic engagement. Contemporary Educational Psychology (Special Issue), 36(1), 13.

Mann, S. and Robinson, A. (2009) Boredom in the lecture theatre: an investigation into the contributors, moderators and outcomes of boredom amongst university students. British Educational Research Journal, 35(2), 243-258. 
Martin, M., Sadlo, G. and Stew, G. (2006) The phenomenon of boredom. Qualitative Research in Psychology, 3(3), 193-211.

Mason, J. (2002) Qualitative researching. London: Sage.

Melton, A.M.A. and Schulenberg, S.E. (2009) A confirmatory factor analysis of the boredom proneness scale. The Journal of Psychology, 143(5), 493-508.

Mercer-Lynn, K.B., Flora, D.B., Fahlman, S.A. and Eastwood, J.D. (2011) The measurement of boredom: differences between existing self-report scales. Assessment, 20(5), 585-596.

Mikulas, W.L. and Vodanovich, S.J. (1993) The essence of boredom. The Psychological Record, 43(1), 3-12.

Miles, M.B., Huberman, A.M. and Saldaña, J. (2014) Qualitative data analysis: a methods sourcebook. London: Sage.

Moroldo, G.K. (1986) Shyness, boredom and grade point average among college students. Psychological Reports, 59(2), 395-398.

Nett, U.E., Goetz, T. and Daniels, L.M. (2010) What to do when feeling bored? Students' strategies for coping with boredom. Learning and Individual Differences, 20(6), 626-638.

Nett, U.E., Goetz, T. and Hall, N.C. (2011) Coping with boredom in school: an experience sampling perspective. Contemporary Educational Psychology, 36(1), 49-59.

O'Hanlon, J.F. (1981) Boredom: practical consequences and a theory. Acta Psychologica, 49(1), 53-82.

Pekrun, R. (1992) The impact of emotions on learning and achievement: towards a theory of cognitive/motivational mediators. Applied Psychology, 41(4), 359376.

Pekrun, R. (2000) A social-cognitive, control-value theory of achievement emotions. In: J. Heckhausen (ed.) Motivational psychology of human development. Oxford: Elsevier Science. 143-163.

Pekrun, R. (2006) The control-value theory of academic emotions: assumptions, corollaries and implications for educational practice. Educational Psychology Review, 18(4), 315-341. 
Pekrun, R., Elliot, A.J. and Maier, M.A. (2009) Achievement goals and achievement emotions: testing a model of their joint relations with academic performance. Journal of Educational Psychology, 101(1), 115-135.

Pekrun, R., Goetz, T., Daniels, L.M., Stupinsky, R.H. and Perry, R.P. (2010) Boredom in achievement setting: exploring control-value antecedents and performance outcomes of a neglected emotion. Journal of Educational Psychology, 102(3), 531-549.

Pekrun, R., Goetz, T., Titz, W.and Perry, R.P. (2002) Academic emotions in students' self-regulated learning and achievement: a programme of quantitative and qualitative research. Educational Psychologist, 37(2), 91-106.

Pekrun, R., Hall, N.C., Goetz, T. and Perry, R.P. (2014) Boredom and academic achievement: testing a model of reciprocal causation. Journal of Educational Psychology, 106(3), 696-710.

Perkins, R.E. and Hill, A.B. (1985) Cognitive and affective aspects of boredom. British Journal of Psychology, 76, 221-234.

Perry, R.P. (2003) Perceived (academic) control and causal thinking in achievement settings: markers and mediators. Canadian Psychologist, 44(4), 312-331.

Perry, R.P., Hechter, F.J., Menec, V.H. and Weinberg, L.E. (1993) Enhancing achievement emotion and performance in college students: an attributional retraining perspective. Research in Higher Education, 34(6), 687-723.

Powney, J. and Watts, M. (1987) Interviewing in educational research. London: Routledge.

Ramsden, P. (2003) Learning to teach in higher education. London: RoutledgeFalmer.

Rupp, D.E. and Vodanovich, J.D. (1997) The role of boredom proneness in selfreported anger and aggression. Journal of Social Behavior and Personality, 12(4), 925-936.

Ruthig, J.C., Perry, R.P., Hall, N.C. and Hladkyj, S. (2004) Optimism and attributional retraining: longitudinal effects on academic achievement, test anxiety and voluntary course withdrawal in college students. Journal of Applied Social Psychology, 34(4), 709-730.

Ruthig, J.C., Perry, R.P., Hladkyj, S., Hall, N.C., Pekrun, R. and Chipperfield, J.G. 
(2008) Perceived control and emotions: interactive effects on performance in achievement settings. Social Psychology of Education, 11(2), 161-180.

Saldaña, J. (2013) The coding manual for qualitative research. London: Sage.

Schönwetter, D.J., Perry, R.P. and Struthers, C.W. (1993) Students' perceptions of control and success in the college classroom. Journal of Experimental Education, 61(3), 227-246.

Schostack, J.F. (2006) Interviewing and representation in qualitative research projects. Buckingham: Open University Press.

Schutz, P.A. and DeCuir, J.T. (2002) Inquiry on emotions and education. Educational Psychologist, 37(2), 125-135.

Schutz, P.A. and Pekrun, R. (eds.)(2007) Emotion in education. Burlington, MA: Academic Press.

Smith, R.P. (1981) Boredom: a review. Human Factors, 23(3), 329-340.

Tashakkori, A. and Teddlie, C. (1998) Mixed methodology: combining qualitative and quantitative approaches. Thousand Oaks, CA: Sage.

Trowler, V. (2010) Student engagement: evidence summary. York: HEA.

Tze, V.M.C., Klassen, R.M., Daniels, L.M. and Li, J.C-H. (2013a) Canadian and Chinese university students' approaches to coping with academic boredom. Learning and Individual Differences, 23, 32-43.

Tze, V.M.C., Klassen, R.M., Daniels, L.M., Li, J.C-H. and Zhang, X. (2013b) A crosscultural validation of the Learning-Related Boredom Scale (LRBS) with Canadian and Chinese college students. Journal of Psychoeducational Assessment, 31(1), 29-39.

Tze, V.M.C., Klassen, R.M. and Daniels, L.M. (2014a) Patterns of boredom and its relationship with perceived autonomy support and engagement. Contemporary Educational Psychology, 39(3), 175-187.

Tze, V.M.C., Daniels, L.M. and Klassen, R.M. (2014b) Examining the factor structure and validity of the English precursors to Boredom Scale. Learning and Individual Differences, 32, 254-260.

Villavicencio, F.T. and Bernardo, A.B.I. (2013) Positive academic emotions moderate 
the relationship between self-regulation and academic achievement. British Journal of Educational Psychology, 83(2), 329-340.

Vodanovich, S.J. (2003a) Psychometric measures of boredom: a review of literature. The Journal of Psychology, 137(6), 569-595.

Vodanovich, S.J. (2003b) On the possible benefits of boredom: a neglected area of personality research. Psychology and Education: An Interdisciplinary Journal, 40(3/4), 28-33.

Vodanovich, S.J. and Kass, S.J. (1990a) A factor analytic study of the boredom proneness scale. Journal of Personality Assessment, 55(1\&2), 115-123.

Vodanovich, S.J. and Kass, S.J. (1990b) Age and gender differences in boredom proneness. Journal of Social Behavior and Personality, 5, 297-307.

Vodanovich, S.J., Watt, J.D. and Piotrowski, C. (1997) Boredom proneness in African-American students: a factor analytic perspective. Education, 118, 229236.

Vodanovich, S.J., Wallace, J.C. and Kass, S.J. (2005) A confirmatory approach to the factor structure of the boredom proneness scale: evidence for a two-factor short form. Journal of Personality Assessment, 85(3), 295-303.

Vogel-Walcutt, J.J., Fiorella, L., Carper, T. and Schatz, S. (2012) The definition, assessment and mitigation of state boredom within educational settings: a comprehensive review. Educational Psychology Review, 24(1), 89-111.

Wallace, J.C., Vodanovich, S.J. and Restino, B. (2003) Predicting cognitive failures from boredom proneness and daytime sleepiness scores: an investigation within military and undergraduate samples. Personality and Individual Differences, 34(4), 635-644.

Watt, J.D. and Vodanovich, S.J. (1999) Boredom proneness and psychosocial development, The Journal of Psychology, 133(3), 303-314.

Weiner, B. (1985) An attributional theory of achievement motivation and emotion. Psychological Review, 92(4), 548-573.

Zimmerman, B.J. and Schunk, D.H. (eds.)(2001) Self-regulated learning and academic achievement: theoretical perspectives. Mahwah, $\mathrm{NJ}$ : Lawrence Erlbaum Associates. 


\begin{tabular}{|c|c|}
\hline Characteristic & Frequency (\%) \\
\hline \multicolumn{2}{|l|}{ Sex } \\
\hline Male & $59(25.1)$ \\
\hline Female & $176(74.9)$ \\
\hline \multicolumn{2}{|l|}{ Age at entry } \\
\hline under 21 & $177(75.3)$ \\
\hline $21-25$ & $42(17.9)$ \\
\hline $26-30$ & $4(1.7)$ \\
\hline $31-40$ & $6(2.6)$ \\
\hline over 40 & $6(2.6)$ \\
\hline \multicolumn{2}{|l|}{ Entry qualifications } \\
\hline A-levels & $204(86.8)$ \\
\hline A-level equivalents & $31(13.2)$ \\
\hline \multicolumn{2}{|l|}{ University generation } \\
\hline First order & $146(62.1)$ \\
\hline Higher order & $89(37.9)$ \\
\hline \multicolumn{2}{|l|}{ Occupational background } \\
\hline Professional & $98(41.7)$ \\
\hline Manual & $133(56.6)$ \\
\hline Other & $4(1.7)$ \\
\hline \multicolumn{2}{|l|}{ Working to earn while studying } \\
\hline Yes & $141(60.0)$ \\
\hline No & $94(40.0)$ \\
\hline \multicolumn{2}{|l|}{ Attendance } \\
\hline Excellent & $153(65.1)$ \\
\hline Good & $72(30.6)$ \\
\hline Satisfactory & $8(3.4)$ \\
\hline Poor & $2(0.9)$ \\
\hline
\end{tabular}

Table 1 Respondent profile $(n=235)$ 


\begin{tabular}{lcc|c|c}
\hline Category & $\mathrm{n}$ & $\begin{array}{l}\text { Mean } \\
\text { score }\end{array}$ & $\begin{array}{l}\text { Standard } \\
\text { deviation }\end{array}$ & Range \\
\hline Low & $40(17.0 \%)$ & 53.9 & 4.29 & $41-59$ \\
\hline Intermediate & $150(63.8 \%)$ & 71.0 & 6.30 & $60-83$ \\
\hline High & $45(19.1 \%)$ & 89.3 & 5.57 & $84-106$ \\
\hline
\end{tabular}

Table 2 Boredom proneness statistics by category based on standard deviation split $(n=235)$ 


\begin{tabular}{|c|c|c|c|c|c|c|c|}
\hline \multirow[b]{2}{*}{ Subscale items } & \multicolumn{3}{|c|}{$\begin{array}{c}\text { Response profile } \\
\text { (frequency and percentage) }\end{array}$} & \multirow[b]{2}{*}{$\begin{array}{c}\text { Mean } \\
\text { score (SD) }\end{array}$} & \multicolumn{3}{|c|}{ Boredom proneness category ${ }^{\dagger}$} \\
\hline & $\begin{array}{l}\text { Always/ } \\
\text { Usually }\end{array}$ & Occasionally & $\begin{array}{l}\text { Rarely/ } \\
\text { Never }\end{array}$ & & $\begin{array}{l}\text { Low } \\
\text { Mean } \\
\text { (SD) }\end{array}$ & $\begin{array}{l}\text { Intermediate } \\
\text { Mean } \\
\text { (SD) }\end{array}$ & $\begin{array}{l}\text { High } \\
\text { Mean } \\
\text { (SD) }\end{array}$ \\
\hline \multicolumn{8}{|l|}{ Tedium } \\
\hline $\begin{array}{l}\text { 28. I've found everything about university } \\
\text { monotonous and tiresome }\end{array}$ & $\begin{array}{c}9 \\
(3.8)\end{array}$ & $\begin{array}{c}44 \\
(18.7)\end{array}$ & $\begin{array}{c}182 \\
(77.4)\end{array}$ & $\begin{array}{c}1.8 \\
(0.86)\end{array}$ & $\begin{array}{c}1.1 \\
(0.34)\end{array}$ & $\begin{array}{c}1.8 \\
(0.74)\end{array}$ & $\begin{array}{l}2.6^{* \star *} \\
(0.96)\end{array}$ \\
\hline $\begin{array}{l}\text { 6. Having to read someone else's course work } \\
{[\ldots \text { presentation/listen ...] bores me tremendously }}\end{array}$ & $\begin{array}{c}27 \\
(11.5)\end{array}$ & $\begin{array}{c}75 \\
(31.9)\end{array}$ & $\begin{array}{c}133 \\
(56.6)\end{array}$ & $\begin{array}{c}2.4 \\
(0.96)\end{array}$ & $\begin{array}{c}1.7 \\
(0.76)\end{array}$ & $\begin{array}{c}2.4 \\
(0.82)\end{array}$ & $\begin{array}{l}3.0^{* * *} \\
(1.13)\end{array}$ \\
\hline $\begin{array}{l}\text { 5. At university, I find myself trapped in situations } \\
\text { where I have to do meaningless things }\end{array}$ & $\begin{array}{l}20 \\
(8.5)\end{array}$ & $\begin{array}{c}84 \\
(35.4)\end{array}$ & $\begin{array}{c}131 \\
(55.7)\end{array}$ & $\begin{array}{c}2.4 \\
(0.89)\end{array}$ & $\begin{array}{c}1.5 \\
(0.60)\end{array}$ & $\begin{array}{c}2.4 \\
(0.70)\end{array}$ & $\begin{array}{l}3.3^{* * *} \\
(0.84)\end{array}$ \\
\hline $\begin{array}{l}\text { 27. At university it seems that we do the same things } \\
\text { all the time - it's getting old }\end{array}$ & $\begin{array}{c}39 \\
(16.6)\end{array}$ & $\begin{array}{c}65 \\
(27.7)\end{array}$ & $\begin{array}{c}131 \\
(55.7)\end{array}$ & $\begin{array}{c}2.5 \\
(1.00)\end{array}$ & $\begin{array}{l}1.6 \\
(0.67)\end{array}$ & $\begin{array}{c}2.4 \\
(0.84)\end{array}$ & $\begin{array}{l}3.5^{* \star *} \\
(0.89)\end{array}$ \\
\hline $\begin{array}{l}\text { 19. At university, it is very hard for me to find a task } \\
\text { that is exciting enough }\end{array}$ & $\begin{array}{l}23 \\
(9.8)\end{array}$ & $\begin{array}{c}84 \\
(35.7)\end{array}$ & $\begin{array}{c}128 \\
(54.5)\end{array}$ & $\begin{array}{c}2.5 \\
(0.83)\end{array}$ & $\begin{array}{c}1.8 \\
(0.73)\end{array}$ & $\begin{array}{c}2.4 \\
(0.64)\end{array}$ & $\begin{array}{l}3.4^{* * *} \\
(0.74)\end{array}$ \\
\hline $\begin{array}{l}\text { 25. Unless I am doing something exciting at university } \\
\text { I feel half dead and dull }\end{array}$ & $\begin{array}{c}45 \\
(19.1)\end{array}$ & $\begin{array}{c}66 \\
(28.1)\end{array}$ & $\begin{array}{c}124 \\
(52.8)\end{array}$ & $\begin{array}{c}2.5 \\
(1.08)\end{array}$ & $\begin{array}{c}1.6 \\
(0.93)\end{array}$ & $\begin{array}{c}2.4 \\
(0.85)\end{array}$ & $\begin{array}{l}3.6^{* \star *} \\
(1.11)\end{array}$ \\
\hline $\begin{array}{l}\text { 12. I find it difficult to get excited about my work at } \\
\text { university }\end{array}$ & $\begin{array}{c}28 \\
(11.9)\end{array}$ & $\begin{array}{c}111 \\
(47.2)\end{array}$ & $\begin{array}{c}96 \\
(40.9)\end{array}$ & $\begin{array}{c}2.7 \\
(0.84)\end{array}$ & $\begin{array}{c}1.8 \\
(0.71)\end{array}$ & $\begin{array}{c}2.7 \\
(0.65)\end{array}$ & $\begin{array}{l}3.4^{\star * *} \\
(0.86)\end{array}$ \\
\hline $\begin{array}{l}\text { 9. At university, many things I have to do are } \\
\text { repetitive and monotonous }\end{array}$ & $\begin{array}{c}33 \\
(14.0)\end{array}$ & $\begin{array}{c}101 \\
(43.0)\end{array}$ & $\begin{array}{c}101 \\
(43.0)\end{array}$ & $\begin{array}{c}2.7 \\
(0.78)\end{array}$ & $\begin{array}{l}2.1 \\
(0.72)\end{array}$ & $\begin{array}{c}2.6 \\
(0.64)\end{array}$ & $\begin{array}{l}3.4^{* * *} \\
(0.72)\end{array}$ \\
\hline 11. At university, I get a kick out of most things I do(r) & $\begin{array}{c}83 \\
(35.3)\end{array}$ & $\begin{array}{c}104 \\
(44.3)\end{array}$ & $\begin{array}{c}48 \\
(20.4)\end{array}$ & $\begin{array}{l}2.8 \\
(0.87)\end{array}$ & $\begin{array}{l}2.1 \\
(0.94)\end{array}$ & $\begin{array}{c}2.8 \\
(0.72)\end{array}$ & $\begin{array}{l}3.5^{* * *} \\
(0.79)\end{array}$ \\
\hline $\begin{array}{l}\text { 18. I often wake up with a new idea for work and other } \\
\text { activities at university }{ }^{(r)}\end{array}$ & $\begin{array}{c}51 \\
(21.7)\end{array}$ & $\begin{array}{c}107 \\
(45.5)\end{array}$ & $\begin{array}{c}77 \\
(32.8)\end{array}$ & $\begin{array}{c}3.1 \\
(0.86)\end{array}$ & $\begin{array}{c}2.5 \\
(0.71)\end{array}$ & $\begin{array}{c}3.1 \\
(0.79)\end{array}$ & $\begin{array}{l}3.7^{* \star *} \\
(0.80)\end{array}$ \\
\hline $\begin{aligned} \text { FSubscale statistics skewness }=0.383, \text { kurtosis } & =0.110 \\
& \text { correlation with degree } r=-.226, p<.001\end{aligned}$ & & & & $\begin{array}{l}2.55 \\
(0.571)\end{array}$ & $\begin{array}{c}1.81 \\
(0.265)\end{array}$ & $\begin{array}{l}2.51 \\
(0.343)\end{array}$ & $\begin{array}{l}3.33^{\star * \star} \\
(0.392)\end{array}$ \\
\hline \multicolumn{8}{|l|}{ Time } \\
\hline $\begin{array}{l}\text { 16. At university, I often find myself with time on my } \\
\text { hands and nothing to do }\end{array}$ & $\begin{array}{c}12 \\
(5.1)\end{array}$ & $\begin{array}{c}57 \\
(24.3)\end{array}$ & $\begin{array}{c}166 \\
(70.6)\end{array}$ & $\begin{array}{c}2.1 \\
(0.84)\end{array}$ & $\begin{array}{c}1.4 \\
(0.59)\end{array}$ & $\begin{array}{c}2.1 \\
(0.76)\end{array}$ & $\begin{array}{l}2.7^{* * \star} \\
(0.76)\end{array}$ \\
\hline $\begin{array}{l}\text { 14. At University, I find myself just sitting around } \\
\text { doing nothing }\end{array}$ & $\begin{array}{l}11 \\
(4.7)\end{array}$ & $\begin{array}{c}52 \\
(22.1)\end{array}$ & $\begin{array}{c}180 \\
(76.6)\end{array}$ & $\begin{array}{l}2.1 \\
(0.81)\end{array}$ & $\begin{array}{c}1.3 \\
(0.44)\end{array}$ & $\begin{array}{c}2.1 \\
(0.63)\end{array}$ & $\begin{array}{l}2.9^{* \star \star} \\
(0.84)\end{array}$ \\
\hline $\begin{array}{l}\text { 4. At university, I find myself at a 'loose end' not } \\
\text { knowing what to do }\end{array}$ & $\begin{array}{l}16 \\
(6.8)\end{array}$ & $\begin{array}{c}71 \\
(30.2)\end{array}$ & $\begin{array}{c}148 \\
(63.0)\end{array}$ & $\begin{array}{c}2.3 \\
(0.84)\end{array}$ & $\begin{array}{c}1.6 \\
(0.59)\end{array}$ & $\begin{array}{c}2.3 \\
(0.75)\end{array}$ & $\begin{array}{l}3.0^{* \star \star} \\
(0.82)\end{array}$ \\
\hline $\begin{array}{l}\text { 13. In any situation at university, I can find something } \\
\text { to do or see to keep me interested } \\
(\text { r) }\end{array}$ & $\begin{array}{c}132 \\
(56.2)\end{array}$ & $\begin{array}{c}84 \\
(35.7)\end{array}$ & $\begin{array}{c}19 \\
(8.1)\end{array}$ & $\begin{array}{c}2.4 \\
(0.82)\end{array}$ & $\begin{array}{c}1.9 \\
(1.13)\end{array}$ & $\begin{array}{c}2.4 \\
(0.99)\end{array}$ & $\begin{array}{l}3.0^{* * \star} \\
(0.66)\end{array}$ \\
\hline $\begin{array}{l}\text { 7. At university, I have no shortage of projects in } \\
\text { mind and things to do(r) }\end{array}$ & $\begin{array}{c}129 \\
(54.9)\end{array}$ & $\begin{array}{c}73 \\
(31.1)\end{array}$ & $\begin{array}{c}33 \\
(14.0)\end{array}$ & $\begin{array}{c}2.4 \\
(1.00)\end{array}$ & $\begin{array}{c}1.7 \\
(0.85)\end{array}$ & $\begin{array}{c}2.5 \\
(0.91)\end{array}$ & $\begin{array}{c}3.0^{* \star *} \\
(1.02)\end{array}$ \\
\hline 3. Time seems to pass by slowly for me at university & $\begin{array}{c}26 \\
(11.1)\end{array}$ & $\begin{array}{c}77 \\
(32.8)\end{array}$ & $\begin{array}{c}132 \\
(56.2)\end{array}$ & $\begin{array}{c}2.4 \\
(0.92)\end{array}$ & $\begin{array}{c}1.7 \\
(0.55)\end{array}$ & $\begin{array}{c}2.4 \\
(0.76)\end{array}$ & $\begin{array}{c}3.2^{\star \star \star} \\
(1.06)\end{array}$ \\
\hline 24. Among my friends at university, I am the one who & 64 & 90 & 81 & 3.0 & 2.6 & 3.1 & $3.2^{* *}$ \\
\hline
\end{tabular}




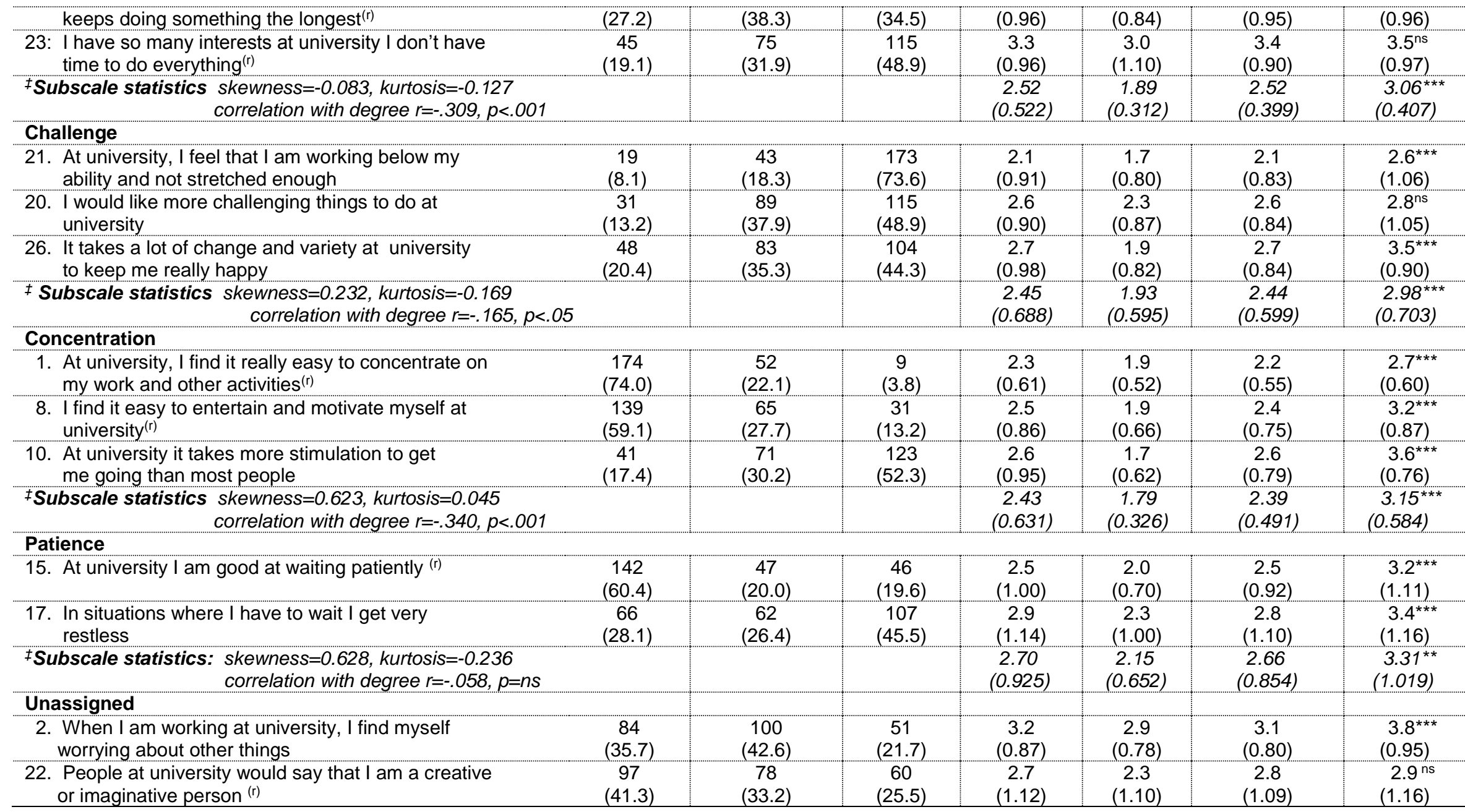

Table 3 BPS-UKHE subscale item profiles and mean values $\left({ }^{r}\right.$ denotes reverse score item; ${ }^{\dagger}$ Kruskal-Wallis $\kappa^{2}$ and $¥$ Anova $F$ : $\mathrm{ns}=$ not significant after Bonferroni correction, $\left.{ }^{* \star} \mathrm{p}<.01,{ }^{* \star *} \mathrm{p}<.001 ; \mathrm{n}=235\right)$ 


\begin{tabular}{|c|c|c|c|c|c|c|c|}
\hline \multirow[b]{2}{*}{ Mode } & \multicolumn{3}{|c|}{$\begin{array}{c}\text { Response profile } \\
\text { (frequency and percentage) }\end{array}$} & \multirow[b]{2}{*}{$\begin{array}{l}\text { Mean } \\
\text { score } \\
(\mathrm{SD}) \\
\end{array}$} & \multicolumn{3}{|c|}{ Boredom proneness category ${ }^{\dagger}$} \\
\hline & $\begin{array}{l}\text { All/Most of } \\
\text { the time }\end{array}$ & $\begin{array}{l}\text { About half } \\
\text { of the time }\end{array}$ & $\begin{array}{c}\text { Some of } \\
\text { the time } \\
\text { /Never }\end{array}$ & & $\begin{array}{l}\text { Low } \\
\text { Mean } \\
\text { (SD) }\end{array}$ & $\begin{array}{c}\text { Intermediate } \\
\text { Mean } \\
\text { (SD) }\end{array}$ & $\begin{array}{l}\text { High } \\
\text { Mean } \\
(\mathrm{SD})\end{array}$ \\
\hline $\begin{array}{l}\text { Individual or very small } \\
\text { group tutorials }\end{array}$ & $\begin{array}{c}166 \\
(70.6)\end{array}$ & $\begin{array}{c}39 \\
(16.6)\end{array}$ & $\begin{array}{c}30 \\
(12.8)\end{array}$ & $\begin{array}{c}3.8 \\
(1.01)\end{array}$ & $\begin{array}{c}4.2 \\
(0.88)\end{array}$ & $\begin{array}{c}3.8 \\
(1.01) \\
\end{array}$ & $\begin{array}{r}3.7^{\mathrm{ns}} \\
(1.10)\end{array}$ \\
\hline Specialised practical input & $\begin{array}{c}154 \\
(65.5)\end{array}$ & $\begin{array}{c}52 \\
(22.1)\end{array}$ & $\begin{array}{c}29 \\
(12.3)\end{array}$ & $\begin{array}{c}3.8 \\
(1.07)\end{array}$ & $\begin{array}{c}4.1 \\
(1.04)\end{array}$ & $\begin{array}{c}3.8 \\
(1.06)\end{array}$ & $\begin{array}{l}3.6^{\mathrm{ns}} \\
(1.10)\end{array}$ \\
\hline Seminars & $\begin{array}{c}159 \\
(67.7)\end{array}$ & $\begin{array}{c}48 \\
(20.4)\end{array}$ & $\begin{array}{c}28 \\
(11.9)\end{array}$ & $\begin{array}{c}3.7 \\
(0.94)\end{array}$ & $\begin{array}{c}4.2 \\
(0.76)\end{array}$ & $\begin{array}{c}3.7 \\
(0.94)\end{array}$ & $\begin{array}{r}3.5^{* *} \\
(0.94)\end{array}$ \\
\hline $\begin{array}{l}\text { Interactive whole-year } \\
\text { lectures }\end{array}$ & $\begin{array}{c}139 \\
(59.1)\end{array}$ & $\begin{array}{c}61 \\
(26.0)\end{array}$ & $\begin{array}{c}35 \\
(14.9)\end{array}$ & $\begin{array}{c}3.5 \\
(0.87)\end{array}$ & $\begin{array}{c}4.1 \\
(0.66)\end{array}$ & $\begin{array}{c}3.5 \\
(0.81)\end{array}$ & $\begin{array}{l}3.0^{* * *} \\
(0.93)\end{array}$ \\
\hline $\begin{array}{l}\text { Online materials available } \\
\text { by VLE (Blackboard) }\end{array}$ & $\begin{array}{c}104 \\
(44.3)\end{array}$ & $\begin{array}{c}78 \\
(33.2)\end{array}$ & $\begin{array}{c}53 \\
(22.6)\end{array}$ & $\begin{array}{c}3.3 \\
(1.10)\end{array}$ & $\begin{array}{c}3.6 \\
(1.13)\end{array}$ & $\begin{array}{c}3.4 \\
(1.10)\end{array}$ & $\begin{array}{l}2.9^{* *} \\
(0.99)\end{array}$ \\
\hline $\begin{array}{l}\text { Traditional whole-year } \\
\text { lectures }\end{array}$ & $\begin{array}{c}109 \\
(46.4)\end{array}$ & $\begin{array}{c}72 \\
(30.6) \\
\end{array}$ & $\begin{array}{c}54 \\
(23.0) \\
\end{array}$ & $\begin{array}{c}3.2 \\
(0.93) \\
\end{array}$ & $\begin{array}{c}3.6 \\
(0.89) \\
\end{array}$ & $\begin{array}{c}3.3 \\
(0.87) \\
\end{array}$ & $\begin{array}{l}2.7^{* \star \star} \\
(0.93)\end{array}$ \\
\hline
\end{tabular}

Table 4 Method of course delivery profiles and mean scores ( ${ }^{\dagger}$ Kruskal-Wallis $\kappa^{2}$ : $\mathrm{ns}=$ not significant after Bonferroni correction, ${ }^{* *} \mathrm{p}<.01,{ }^{* *} \mathrm{p}<.001 ; \mathrm{n}=235$ ) 


\begin{tabular}{l|c|c|c|c|c}
\hline Variable & $\begin{array}{c}\text { BPS-UKHE } \\
\text { (full scale) }\end{array}$ & $\begin{array}{c}\text { Self-study } \\
\text { (hours) }\end{array}$ & $\begin{array}{c}\text { Attendance } \\
(\mathrm{rs})\end{array}$ & $\begin{array}{c}\text { Work to earn } \\
\text { (hours) }\end{array}$ & $\begin{array}{c}\text { Degree } \\
(\%)\end{array}$ \\
\hline BPS-UKHE (full scale) & - & $-.295^{\star \star *}$ & $-.337^{\star * *}$ & -.013 & $-.315^{\star \star \star}$ \\
\hline Self-study (hours) & & - & $.168^{\star *}$ & -.059 & $.149^{*}$ \\
\hline Attendance (rs) & & & - & -.105 & $.296^{\star * \star}$ \\
\hline Work to earn (hours) & & & & - & -.111 \\
\hline Degree (\%) & & & & & - \\
\hline
\end{tabular}

Table 5 Pearson correlation matrix ( $\mathrm{r}_{\mathrm{s}}$ Spearman for attendance; ${ }^{*} \mathrm{p}<.05,{ }^{* *} \mathrm{p}<.01,{ }^{* * *} \mathrm{p}<.001$; $\left.\mathrm{n}=235,{ }^{\dagger} \mathrm{n}=141\right)$ 


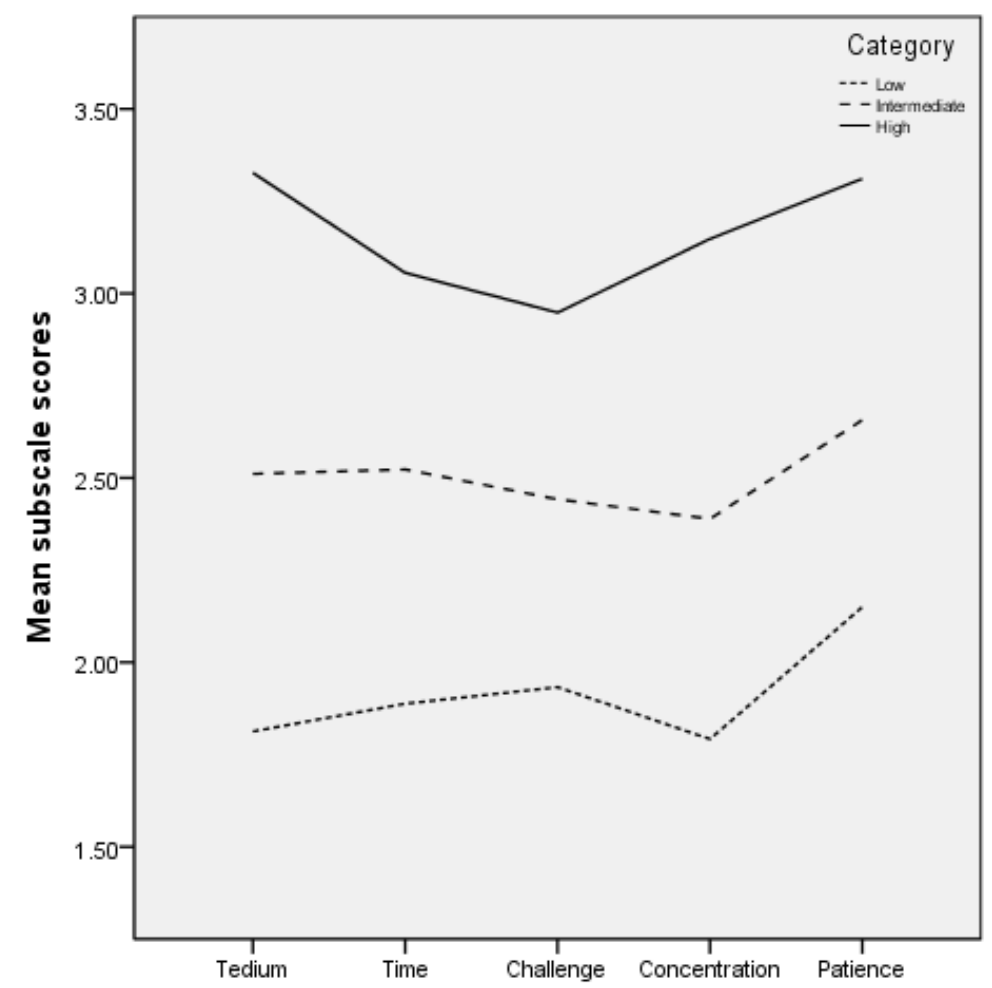

Figure 1 BPS-UKHE subscale profiles split by boredom proneness category (overall $n=235$ ) 


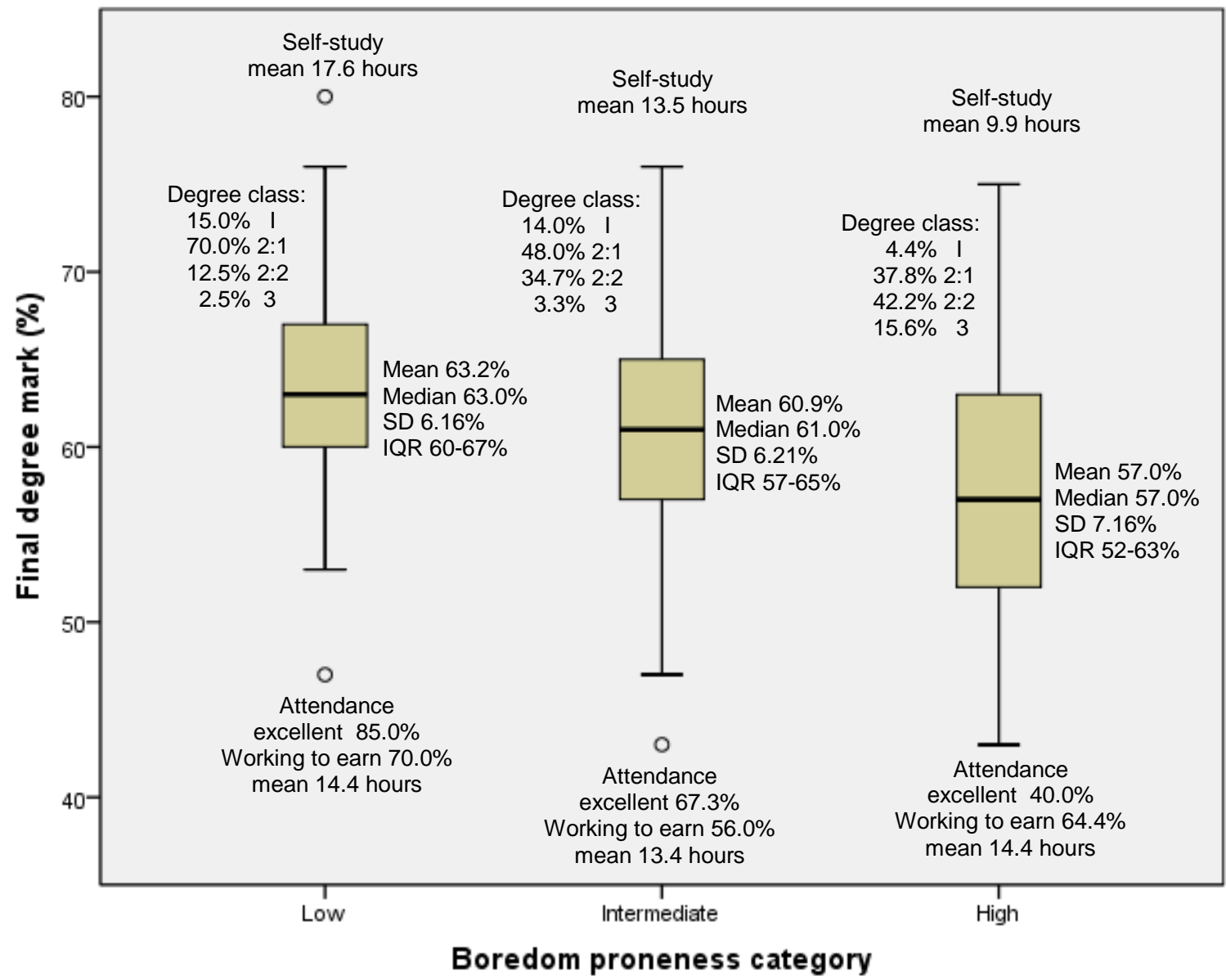

Figure 2 Final degree mark split by boredom proneness category (overall $n=235$; working to earn $n=141$ ) 